\title{
ROLES OF E-SERVICE IN ECONOMIC DEVELOPMENT, CASE STUDY OF NIGERIA, A LOWER-MIDDLE INCOME COUNTRY
}

\author{
Kazeem Oluwakemi Oseni and Dr. Kate Dingley \\ University of Portsmouth, Portsmouth, United Kingdom
}

\begin{abstract}
E-Government activities are still very low in Nigeria, a lower middle-income country, and this is hindering E-Service adoption. E-Service is inextricably linked to E-Government and they will not develop separately, but as one progresses the other moves forward. Having a new technology like E-service opens new opportunities for government, private and public sectors. Despite the fact that the new technology will not be without a hindrance, the overall benefits of using outweigh its lapses.

Nigeria has overtaken South Africa as top Africa economy. There is still more to be done in increasing the revenue of the country, reducing the huge external debt owing the World Bank. Furthermore, there is a need to sustain the new status as top economy in Africa. There are many unresolved problems like corruption. This leads to a slow movement of files in offices, embezzlement, election irregularities, and port congestions among others. Adoption of E-Service will help to reduce these problems and increase the revenue base of the country.

This study will identify e-Service roles in economic development in Nigeria, a lower middle-income country. The study is based on literature review methodology and recent online survey that shows the level of E-Service awareness and roles. We shall also examine previous conference papers related to this study and necessary recommendations will be suggested and offered to the authority in Nigeria on how best the e-service adoption will add more success to the economic development.
\end{abstract}

Keywords: E-Service, Roles of E-Service, E-Government, Economic Development, Nigeria.

\section{INTRODUCTION}

The introduction of new technology opens new opportunities for private and public sectors and eservices are no exceptions. Though, they face a number of challenges [11]. Governments in most developed and developing countries will like to implement e-service such as e-procurement technology in Malaysia. This will enhance transparency and accountability [3].

Though, the governments of developed nations have realised that the provision of essential public services cannot be shouldered alone. The complication in demand patterns coupled with the limitation in resources have brought about the need for public-private collaboration [24]. In some developed countries, public-private collaboration involves in the coming together of the government, private businesses and the society at large. The aim is to provide public e-services for economic development and to achieve a common objective [32].

Information system has improved the operations in organisations both private and public. It has contributed immensely to economic development as manual based operation has now shifted to computer based [17]. E-Service transactions have now to a large extent faced out face to face and telephone based transactions [18]. The Cashless economy policy introduced by Central Bank of

DOI : 10.5121/ijmit.2015.7202 
Nigeria (CBN) in 2012 has been effective. Apart from reducing the manual cash handling in the public, Nigeria has overtaken South Africa as top Africa economy [6].

This paper is of interest to the government officials and public because e-government activities in Nigeria are low and huge revenue is lost annually due to manual documentation. The study will examine the roles of e-service in economic development as well-enlightening public the need to adopt e-service in the country considering the overall benefits.

\section{LITERATURE REVIEW}

There are related research papers on e-Service, adoption and implementation [1]; [4];[6]; [7];[12];[10]; [18]. There is no current research paper on the role of e-Service in economic development in Nigeria. This shows the important of this study. Despite the fact that level of egovernment services in Nigeria is still very low [21].

The current e-service applications in the country have helped in the revenue boost [6]. Government need to improve in ICT provision both telecommunication and infrastructure. The coming of mobile communication into the country in 2001 has increased the economic strength of the country because of rapid growth in the sector [1].

The concept of e-Government, e-Service, Nigeria economic development and the roles of eService in Nigeria economic development will form the next section of this study.

\subsection{E-Government}

The concept of e-government emerged in the late 1990s despite that the history of computing as a tool in government establishments could be traced back to the origin of computer itself and just like other e-platform concept such as e-commerce, the term e-government was born out of internet world [2]. Few decades ago, e-Government as a term and as an identified activity was unknown before now and because of rapid growth, there is possible future direction for the research domain [14].

It is important to know that "E-Government initially began as an intra-governmental communication tool" according to [28] shortly before government organizations developed their websites with various useful information. Online transactions started immediately the information of government unit websites have been mastered followed by private sector's focus on electronic commerce [28].

Moreover, it should be noted that the term e-Government is more than just websites where email or processing of transaction is being done using internet, e-Government has become part of technological advancement in our knowledgeable society of today. New concepts have been added to e-Government which includes accountability, transparency and evaluation of government performance through citizen's participation [20].

\subsection{E-Service Concept}

E-Service as a term is not only about "electronic" and "service" as argued by [29] but the true eservice operation may be where part if not all interaction between service provider and customer is done via internet. This was also substantiated by [30]. E-Service known as electronic service is the service provided through electronic medium like mobile, kiosk and online [7]. 
E-Service concept unites the important trends in the business world, the shifting of the economy from goods to services [25]. The quick development of information and electronic networks has helped in e-service growth[25]. In Nigeria today, most government and private agencies still depend on employee's honesty to give accurate account in using public funds and collection of revenue to support economy development [10]. Information technology through e-service in this area is seen as an enabler to give appropriate and open accountability in revenue and resource management [10] due to high corruption in the country [6].

The role of information technology in economic development cannot be measured as e-service has helped to check fraudster's activities in the collection of various government revenues in Nigeria [15]. The living standard of citizen could be improved with developmental projects if fund is available [15]. Governments should avoid consequences connected with technological change be it economic or social [4]. Though, there are many benefits with the use and application of digital and e-Government services [4].

However, the use of the technology (e-Service) might not be able to totally remove challenges facing the economic growth. It will, therefore, encourage the actualization of economic development goals through prompt availability and exchange of information [15].

\subsection{Nigeria Economic Development}

This section provides a review of economic developments in Nigeria with trends in the major macroeconomic variables [16]. Nigeria has always played a major economic role in the world. Nigeria is the largest black nation, and the economy of Nigeria is the largest and one of the most developed economies in Africa [34]. Considering the abundant human and material resources in Nigeria, the economic development is still hampered by numerous challenges like bad leadership and management [27].

The economic performance of Nigeria does not reflect resource endowments. Though, there is considerable progress in the economy [27]. Discussion on economic development focus on Gross Domestic Product (GDP) Growth Summary and inflation rate for 2011 and 2012 as presented in Table 1, Figures 1, 2 and 3 below [16].

\begin{tabular}{|l|c|c|c|c|c|c|c|c|}
\hline \multicolumn{1}{|c|}{ Sectoral Growth (\%) } & $\mathbf{2 0 1 1}$ & & & & $\mathbf{2 0 1 2}$ & & & \\
\hline & $\mathbf{Q 1}$ & $\mathbf{Q 2}$ & $\mathbf{Q 3}$ & $\mathbf{Q 4}$ & $\mathbf{Q 1}$ & $\mathbf{Q 2}$ & $\mathbf{Q 3}$ & $\mathbf{Q 4}^{\mathbf{f}}$ \\
\hline Agriculture & 5.31 & 5.7 & 5.76 & 5.68 & 4.37 & 4.21 & 3.89 & 3.83 \\
\hline Solid Mineral & 12.9 & 11.85 & 12.43 & 12.85 & 11.65 & 11.72 & 12.61 & 12.68 \\
\hline $\begin{array}{l}\text { Crude Petroleum \& Natural } \\
\text { Gas }\end{array}$ & 0.05 & 0.98 & -0.26 & -0.08 & -2.32 & -0.73 & 0.08 & -0.17 \\
\hline Manufacturing & 6.13 & 7.2 & 7.84 & 7.63 & 5.17 & 7.59 & 7.78 & 7.71 \\
\hline Telecommunication \& Post & 32.14 & 34.1 & 35 & 36.39 & 34.06 & 29.38 & 31.57 & 32.5 \\
\hline Finance \& Insurance & 1.07 & 1.37 & 1.01 & 3.12 & 3.57 & 5.01 & 1.08 & 3.17 \\
\hline Wholesale and Retail Trade & 10.06 & 11.43 & 11.8 & 11.92 & 8.42 & 8.65 & 9.62 & 10.76 \\
\hline Building and Construction & 13.19 & 11.98 & 10.88 & 12.09 & 13.28 & 12.73 & 11.52 & 12.6 \\
\hline Hotel and Restaurants & 12.2 & 12.39 & 11.96 & 12.01 & 11.45 & 12.3 & 12.33 & 12.69 \\
\hline Real Estate & 9.51 & 10.54 & 10.86 & 11.16 & 9.34 & 10.81 & 10.24 & 11.1 \\
\hline Business and Other Services & 8.62 & 11.03 & 8.52 & 9.81 & 7.67 & 11.26 & 9.11 & 10.69 \\
\hline Other sectors & 4.68 & 4.6 & 5.04 & 5.5 & 4.97 & 4.84 & 5.25 & 5.78 \\
\hline Real Growth at Basic Prices & $\mathbf{6 . 9 6}$ & $\mathbf{7 . 5}$ & $\mathbf{7 . 3 7}$ & $\mathbf{7 . 7 6}$ & $\mathbf{6 . 3 4}$ & $\mathbf{6 . 3 9}$ & $\mathbf{6 . 4 8}$ & $\mathbf{7 . 0 9}$ \\
\hline \multicolumn{1}{|c|}{ Non - Oil Growth } & $\mathbf{8 . 5 2}$ & $\mathbf{8 . 7 2}$ & $\mathbf{8 . 7 6}$ & $\mathbf{9 . 1}$ & $\mathbf{8 . 1 4}$ & $\mathbf{7 . 6 3}$ & $\mathbf{7 . 5 5}$ & $\mathbf{8 . 2 3}$ \\
\hline
\end{tabular}

Table 1. Nigeria GDP Sectoral Growth Summary for 2011 and 2012 [16] 
International Journal of Managing Information Technology (IJMIT) Vol.7, No.2, May 2015

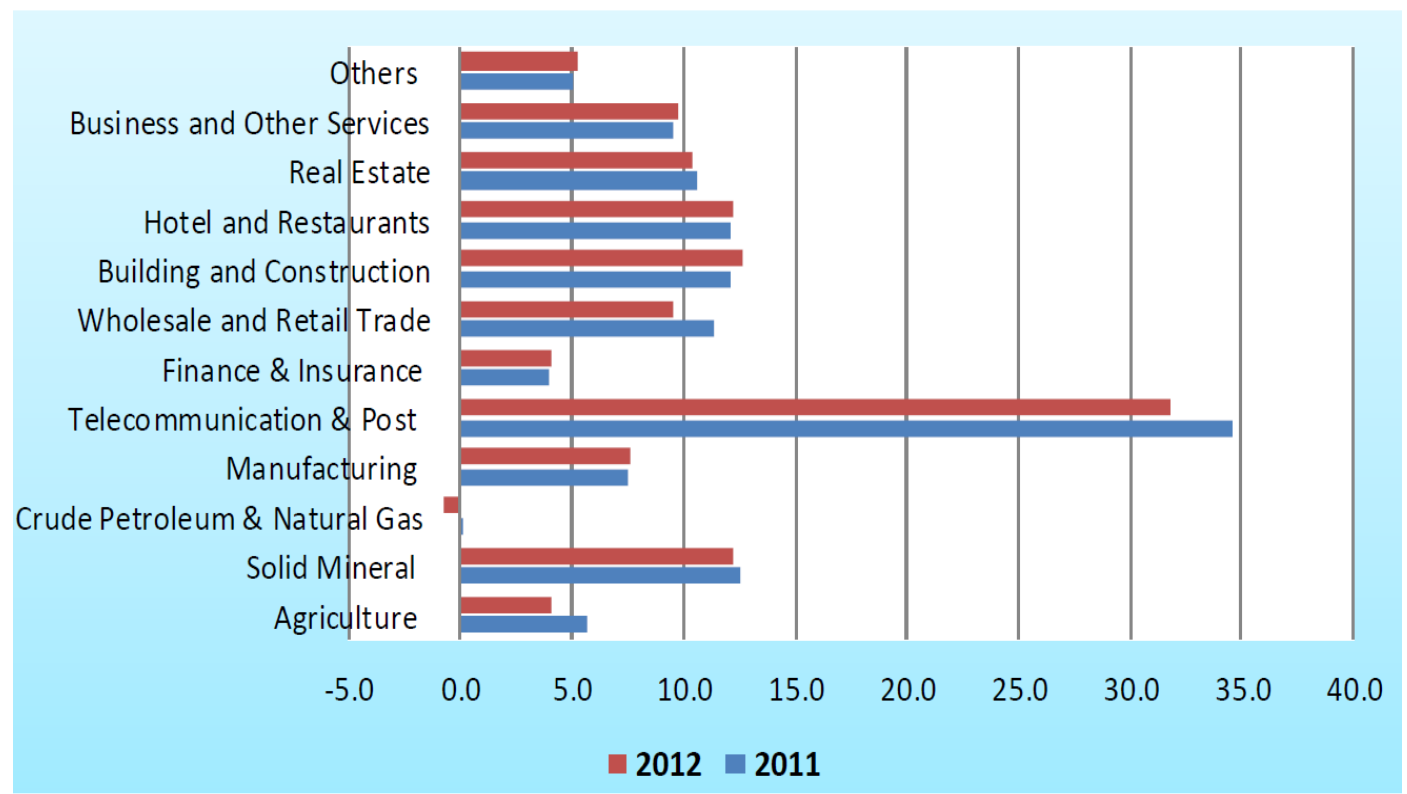

Figure 1. Sectoral growth in Real GDP (\%) 2011-2012 [16]

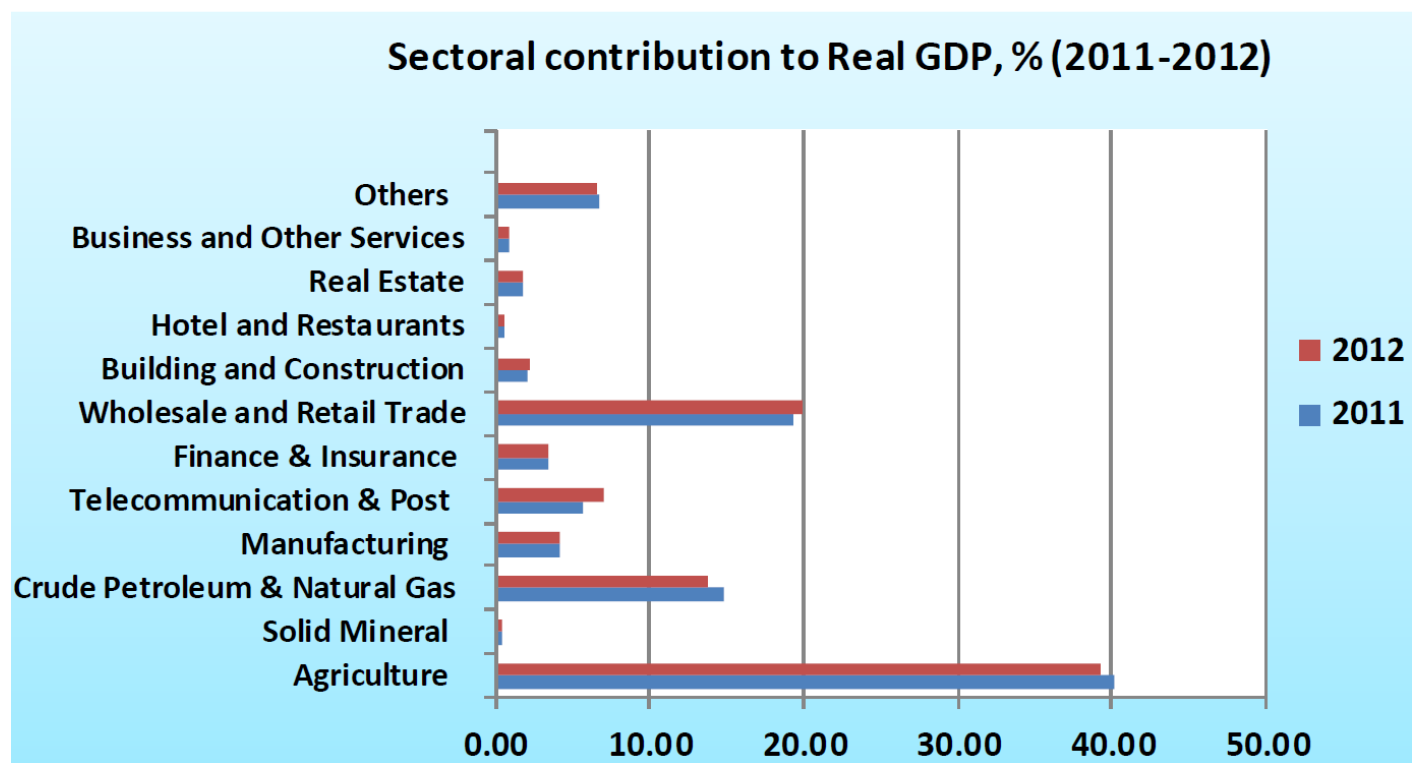

Figure 2: Sectoral contribution to Real GDP growth, 2011-2012 [16] 
International Journal of Managing Information Technology (IJMIT) Vol.7, No.2, May 2015

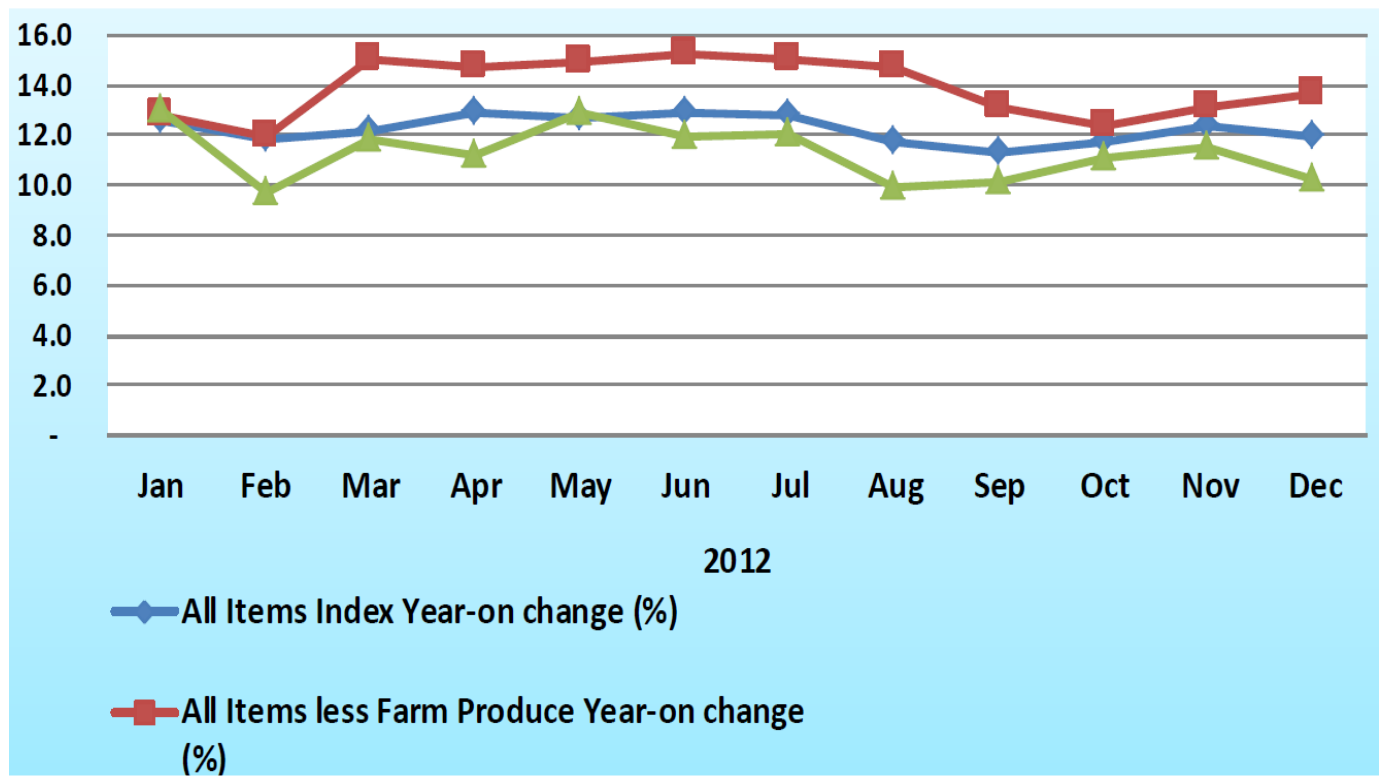

Figure 3: Trends in monthly inflation rates in $2012(\%)$ [16].

The Table 1 and Figures 1, 2 and 3 above indicates role of E-Services in Nigeria's economic development focusing on Gross Domestic Product (GDP) Growth Summary and inflation rate for the year 2011 and 2012 [16].

\subsection{E-Service Roles in Nigeria Economic Development}

This section provides a review of e-Service roles in Nigeria economic development. Though, the economic performance in Nigeria has been very slow compared to many Asia countries that were behind Nigeria about few decades ago [27]. The Asia countries have transformed economies that made them major players in the global economic arena and Nigeria can learn lessons from them [27].

Political stability and security are vital in establishing a conducive environment for economic growth as technology use will support exports [27]. Though, Nigeria is presently witnessing political instability even that has not stopped the economy to become the largest in Africa [34].

Despite the huge revenue made by government in Nigeria through deployment of e-Services in government's operations [6] and facilities for users to give online feedback [9]. Recent study showed that $70 \%$ of Nigeria state websites are still in publishing stage of e-government with $30 \%$ having reached the second stage [21].

The following have been identified by [19] as major roles e-Service has played in Nigeria economic development.

1. Facilitating employment through ICT tools/ Job creation

2. Bridging the cultural gap.

3. E-Participation \& Governance, Democracy.

4. Local content.

5. Gender empowerment

Employment: The creation of jobs through ICT enable platform has improved in Nigeria. Capacity building has contributed to huge revenue government is making annually [19]. A 
International Journal of Managing Information Technology (IJMIT) Vol.7, No.2, May 2015

typical example is the European Commission Mutual Learning Programme for Public Employment Services (PES) and E-services. Self-help tools were developed for job-seekers making it easier to networking, using step by step guidelines towards work [22].

Cultural Gap: The provision of e-services in Nigeria has help to bridge cultural gap [19]. Different cultures now have mutual understanding on how to network together. This is possible as citizens have benefitted from the availability of e-services in the areas like education [19].

E-Participation \& Governance, Democracy: Awareness has been improved in the eparticipation and governance domain [19]. People are now aware of the benefit of paying tax regularly and easier online platforms have been designed to pay and monitor the evaders [6]. Cashless economy introduces in Nigeria in 2012 have reduced the manual cash handling in the public. Nigeria has overtaken South Africa as top Africa economy [6].

Local Content: Export of goods are improving, records keeping is now excellent through provision of e-services in Nigeria. E-service is committed to building capacity to support business and capability of the local people for economic development [19].

Gender Empowerment: This is described as a process by which women could overcome many obstacles confronting them such as employment, education, health care [5]. This has been made easy using ICT enabling platforms [19].

\section{RESEARCH METHODOLOGY}

The methodology for this research work is in two folds [4]. The first one based on a review of previous studies [3]; [6]; [9]; [13]; [15]; [16];[19]; [27] and the second part of the methodology is the survey using online questionnaires [23] sent to participants on the awareness and usefulness of e-service. The objective of this study is to examine the roles of e-Service in economic development of Nigeria. This is an impact study and multiple research methods are adopted [26]. In this study, the questionnaires were designed to help in data collection and the questions are into two categories as used by [6]; [23]. Demography was used and validated by [20]; [31]. The second part of the questionnaires is about e-Service awareness and usage whose questions have been used and validated by [31]

\section{Analysis of findings}

Early research results and findings were based on studying related works on the roles of e-Service in economic development of Nigeria [3]; [6]; [9]; [13]; [15]; [16];[19]; [27] and the outcome of the online survey [23]. Though, there are still many challenges facing the full implementation of eServices in various aspect of the economy [27].

The findings shows that e-Service has contributed immensely to the economic development of Nigeria as summarised by [9] in the areas such as job creation through the use of ICT tools, increase in local content, port decongestion, an increase in revenue through e-tax and high eParticipation awareness. It has a major boost and substantial influence on customer reactions towards e-Governance [27].

In recent survey conducted by the authors between 23th September and $30^{\text {th }}$ October 2014 for the purpose of this paper and from the result shows below, $83(69 \%)$ were males and $33(28 \%)$ females, and 4 respondents avoided the question. Questionnaires have been designed in such a way that respondents could still answer the next question despite skipping the previous question. More participants in the age range 20-39 participated in the survey with $61 \% .102$ out of 120 
participants, who participated in the questionnaires, have now heard of e-Service (awareness level). 49 E-Service Users were satisfied with the service, 9 extremely satisfied with 29 neutral (undecided). 24 users were not satisfied and 3 users were extremely dissatisfied. The detailed survey results and analysis are in the previous paper by the authors [23] with the title Challenges of e-Service Adoption and Implementation in Nigeria: Lessons from Asia [33].

\section{CONCLUSION AND RECOMMENDATIONS}

We have been able to examine the roles of e-service in Nigeria economic development. Despite low e-Governance activities in Nigeria [21], successful e-Service implementation will continue to increase revenue and aid economic development. With findings above, future research is needed to identify and implement cost-effective, usable e-Service systems for the country. Good leadership management, awareness and availability of e-Services are recommended in order to have a more robust economy. More indicators of good governance could be added to these ideas for more realistic finding and more acceptable outcomes.

\section{ACKNOWLEDGMENTS}

The authors would like to thank everyone.

\section{REFERENCES}

[1] Adeyemo A.B (2011) E-government implementation in Nigeria: An assessment of Nigeria's global egovernment ranking Journal of internet and information system Vol. 2(1), pp. 11-19.

[2] Ake Gronlund and T.A Horan (2004) "Introducing E-government: History, Definitions and Issues, Communications of the Association for Information Systems, Volume 15, Page 713-729.

[3] Arjun Neupane, Jeffrey Soar, Kishor Vaidya, and Jianming Yong (2012) Role of Public EProcurement Technology to reduce Corruption in Government Procurement. International Public Procurement Conference, August 17-19, Seattle, Washington.

[4] Asgarkhani M (2005) "The Effectiveness of e-Service in Local Government: A Case Study" The Electronic Journal of e-Government Volume 3 Issue 4, pp 157-166.

[5] Ashokan, S.R and G. Singh (2002) Socio-economic Empowerment of Rural Women through AgroBusiness Consortium. A Success Story of Samridhi Mahila Cooperative in Himachal Pradesh. Political Economy Journal of India.

[6] Ayoola T. J (2013) The effect of Cashless Policy of Government on Corruption in Nigeria, The International Review of Management and Business Research, Vol 2, Iss 3.

[7] Bhuiyan, M.S.H (2011) "Public Sector eService Development in Bangladesh: Status, Prospects and Challenges" Electronic Journal of e-Government Vol. 9, Issue 1, (pp15 - 29).

[8] Danish Dada (2006) "The failure of e-Government in Developing Countries: A Literature Review" The Electronic Journal on Information Systems in Developing Countries, Vol. 26, Iss. 1. Pg. 1-10

[9] Fatile, Jacob Olufemi (2012) Electronic Governance: Myth or Opportunity for Nigerian Public Administration? International Journal of Academic Research in Business and Social Sciences September 2012, Vol. 2, No. 9 ISSN: 2222-6990

[10] Gberevbie Daniel et. al (2014)The Role of Information and Communication Technology on Transparency, Trust and Good Governance in Nigeria. Electronic Journal of E-Government, Romania.

[11] Goran Goldkuhl and Erik Perjons (2014) Focus, goal and Roles in E-Service Design: Five Ideal Types of the Design Process. E-Service Journal, Volume 9, Issue 2, Page 24-45.

[12] Hassan H.S, E. Shehab and J. Peppard (2011) Recent advances in e-service in the public sector: Stateof-the-art and future trends, Business Process Management Journal, Vol. 17 No. 3, pp. 526-545, Emerald Group Publishing Limited.

[13] Haque, S., \& Pathrannarakul, P. (2013). The Role of Technology in Enhancing Transparency and Accountability in Public.

[14] Heeks, Richard, and Savita Bailur (2007) "Analyzing e-government research: Perspectives, philosophies, theories, methods, and practice." Government information quarterly 24.2, pp 243-265. 
International Journal of Managing Information Technology (IJMIT) Vol.7, No.2, May 2015

[15] Ikponmwosa, O. and Ezomo, P.I. (2013) "ICT for National Development in Nigeria: Creating an Enabling Environment." International Journal of Engineering and Applied Sciences, Volume 3, No. 2, pp 59-66.

[16] Kale, Yemi (2013) Economic Outlook for the Nigeria Economy (2013-2016), National Bureau of Statistics.

[17] Lenk, K. (2002) Electronic Service Delivery - A driver of public sector modernization, Information Polity, Volume 7 pages 87-96.

[18] Lindgren, I. (2013) Public e-Service Stakeholders: A study on who matters for public e-service development and implementation, Sweden Publication, Ipswich, MA.

[19] Matthew Perkins (2010) Impact of ICT and e-Services on Social and Economic Development, United Nations Economic and Social Commission for Western Asia.

[20] Mohammed Alshehri and Stew Drew (2010) "Challenges of e-Government Services Adoption in Saudi Arabia from e-Ready Citizen Perspective" Journal of World Academy of Science, Engineering and Technology, Vol. 4, No. 6

[21] Mundy, D and Musa, B (2010) "Towards a Framework for e-Government Development in Nigeria" Electronic Journal of e-Government, Volume 8, Issue 2, PP148-161.

[22] Murray, Ellen (2011) The European Commission Mutual Learning Programme for Public Employment Services (PES), PES and E-services, Amsterdam.

[23] Oseni, K., and Dingley, K. (2014). Challenges of e-Service Adoption and Implementation in Nigeria: Lessons from Asia. World Academy of Science, Engineering and Technology, International Science Index, Information Engineering, 2(9), 135.

[24] Préfontaine L. (2002) "New Models of Collaboration for the Implementation of Public Service", Connecting research and practice National Conference for Digital Government Research Los Angeles.

[25] Rust, R. (2001). The rise of e-service. Journal of Service Research, 3(4), 283-284.

[26] Samuel Gowon Edoumiekumo and Chris O. Opukri (2013) Economic Growth Factor in Nigeria: The Role of Global Trade, American Journal of Humanities and Social Sciences Vo1. 1, No. 2, 51-55.

[27] Sanusi L. Sanusi (2012) Nigeria's Economic Development Aspirations and the Leadership Question; Is there a Nexus? Distinguished Annual Lecture Delivered at the 2nd General Dr. Yakubu Gowon, Nigeria.

[28] Schwester, R. (2009) Examining the barriers to e-Government Adoption. Electronic Journal of eGovernment, Vol 7(1).

[29] Sukasame, N. (2004) The development of e-service in Thai government. BU Academic Review 3.1, pg. 17-24.

[30] Surjadjaja, H., Ghosh, S., \& Antony, F. (2003) "Determining and assessing the determinants of eService operations.” Managing Service Quality Journal, Volume 13 (1), pages 39-53.

[31] Susanto, T.D and R. Goodwin (2010) "Factors Influencing Citizen Adoption of SMS Based eGovernment Services" Electronic Journal of e-Government, Volume 8, Issue 1, pages 55-71.

[32] United Nations Foundation (2004) "A Draft on Governance in Public Private Partnerships for Infrastructure Development", Geneva.

[33] www.waset.org/Publications/?path=Publications\&p=96

[34] www.aljazeera.com

\section{AUTHORS}

Kazeem Oluwakemi Oseni is a PhD Candidate in the School of Computing, University of Portsmouth, United Kingdom

Dr. Kate Dingley is a Principal Lecturer in the School of Computing, University of Portsmouth, United Kingdom 